\title{
Media Buku Cerita untuk Meningkatkan Kemampuan Membaca dan Menulis Siswa Kelas IV Sekolah Dasar
}

\author{
Irma Nugraheni ${ }^{1}$, Titik Harsiati ${ }^{2}$, Abd Qohar ${ }^{3}$ \\ ${ }^{1}$ Pendidikan Dasar-Universitas Negeri Malang \\ ${ }^{2}$ Pendidikan Bahasa Indonesia-Universitas Negeri Malang \\ ${ }^{3}$ Pendidikan Matematika-Universitas Negeri Malang
}

\section{INFO ARTIKEL}

\section{RiwayatArtikel:}

Diterima: 06-11-2018

Disetujui: 14-03-2019

\section{Kata kunci:}

storybook; the ability to read and write; elementary school students; buku cerita:

kemampuan membaca dan menulis; siswa sekolah dasar

\author{
Alamat Korespondensi: \\ Irma Nugraheni \\ Pendidikan Dasar \\ Universitas Negeri Malang \\ Jalan Semarang 5 Malang \\ E-mail: nistyy.irma@gmail.com
}

\begin{abstract}
ABSTRAK
Abstract: This research was aimed to produced a new products in the form of storybooks with a focus on Theme 1, namely the Beautifulness of Togetherness in the Subtema of Cultural Diversity in My Country to improve the ability to read and write fourth grade students. The development model used in this study is Dick \& Carey. The selection of the development model is based on goal-oriented and results that can be used to create an optimal learning. The Dick \& Carey development model has 10 stages in development. In this study only use until the 9th stage, because in this story book does not provide summative evaluation.

Abstrak: Penelitian ini bertujuan untuk menghasilkan produk baru berupa buku cerita dengan fokus pada Tema 1 yaitu Indahnya Kebersamaan Subtema Keberagaman Budaya Bangsaku untuk meningkatkan kemampuan membaca dan menulis siswa kelas IV SD. Model pengembangan yang digunakan pada penelitian ini adalah Dick \& Carey. Pemilihan model pengembangan tersebut didasarkan oleh berorientasi pada tujuan serta hasil yang dapat digunakan untuk menciptakan sebuah pembelajaran yang optimal. Model pengembangan Dick \& Carey mempunyai 10 tahapan dalam pengembangan. Pada penelitian ini hanya menggunakan sampai pada tahap kesembilan saja dikarenakan pada buku cerita ini tidak menyediakan evaluasi sumatif.
\end{abstract}

Media dalam sebuah pembelajaran merupakan komponen yang berpangaruh untuk mencapai tujuan belajar. Media pembelajaran memainkan peran penting dalam meningkatkan keberhasilan proses pembelajaran (Fahmi, 2017). Penggunaan media dalam kegiatan belajar mengajar siswa akan lebih termotivasi untuk belajar. Hal itu sesuai dengan yang diungkapkan oleh (Nugraha, 2016), individu yang termotivasi merupakan individu yang memiliki fokus pada pentingnya upaya dan ketekunan dalam belajar. Ketersediaan media juga akan membuat siswa dapat berpatisipasi aktif dalam kegiatan pembelajaran. Hal tersebut sesuai dengan prinsip-prinsip belajar mengajar sebagaimana dalam buku Kurikulum dan Pembelajaran, Hamalik (2011) mengemukakan bahwa prinsip-prinsip belajar mengajar salah satunya yaitu peserta didik belajar dengan berbuat dan mengalami langsung serta keterlibatan secara aktif dalam lingkungan belajar. Kelas dengan ketersediaan media di dalam pembelajarannya akan menghasilkan siswa yang berbeda dengan kelas yang tidak menyediakan media di dalam pembelajarannya. Siswa dengan pembelajaran menggunakan media akan jauh lebih aktif daripada siswa yang pada pembelajaran tidak pernah sama sekali menggunakan media. Berbeda dengan teman sekelas 'pasif' mereka, siswa yang proaktif mengatur dirinya sendiri mencari informasi dan mengadopsi tindakan apa saja yang diperlukan untuk mengendalikannya (Nugraha, 2016).

Media pembelajaran juga dapat digunakan sesuai dengan karateristik pengguna, baik secara individu maupun secara kelompok. Sebagaimana dalam buku AV Instruction Technology, Media, and Methods, Brown (2013) mengemukakan bahwa Media pendidikan dari semua jenisnya mempunyai peran dan memungkinkan siswa untuk mendapatkan manfaat dari media tersebut meskipun dalam pembelajaran secara individual. Pembuatan media dapat disesuaikan dengan karakteristik dari pengguna media. Pada lingkungan sekolah tradisional/pedesaan, perencanaan pembelajaran dalam jangka panjang diperlukan perencanaan yang terstruktur, sumber daya media yang dipilih juga dapat dijadwalkan secara tetap (Brown, 2013).

Media pembelajaran dapat dikemas berupa buku cerita anak-anak yang dilengkapi dengan gambar yang sesuai dengan topik pada cerita. Penambahan gambar pada setiap cerita ini harus melihat dari karakteristik pada setiap cerita sehingga mampu mewakili sesuatu yang tersirat dalam cerita. Buku cerita bergambar memiliki alur yang benar-benar bercerita, ilustrasi dalam buku cerita bergambar memiliki peran yang sama pentingnya dengan teksnya (Faizah, 2009). Ketersediaan gambar dalam setiap 
cerita ini diharapkan mampu memberikan gambaran awal pembaca untuk menebak tentang cerita yang akan dibaca. Buku cerita bergambar harus di evaluasi sesuai dengan kualitas gambar dan ceritanya (Stewig, 2008). Pembelajaran yang memanfaatkan buku cerita sebagai media dalam proses belajarnya, alangkah baiknya jika proses penggunaan cerita tersebut secara berkesinambungan sehingga siswa akan lebih mudah dalam memahami cerita. Sesuai dengan pernyataan dari Carr (2012), ketika saya mulai menulis pembelajaran dengan menggunakan cerita dengan menggunakan indikator baru, saya menjadi sadar bahwa cerita yang benar-benar menggairahkan saya pada umumnya adalah cerita baru yang diilustrasikan lebih dari satu indikator. Nilai karakter positif dalam cerita anak dapat dijadikan suatu pembelajaran bagi anak-anak yang membacanya (Nurmanita, 2017).

Buku cerita bergambar ini juga sangat disukai pada kalangan anak-anak karena tampilannya yang mampu menarik perhatian. Cerita anak adalah cerita berbagai kejadian yang sesuai yang dapat dijangkau dan dipahami oleh pembaca anak-anak (Nurjanah, 2018). Proses pembuatan buku cerita bergambar ini juga harus sesuai dengan tujuan awal yang sudah dirancang sebelumnya. Untuk memahami mengapa buku bergambar harus menjadi bagian yang sangat penting dari lingkungan anak-anak, penting untuk mengidentifikasi beberapa tujuan yang mereka layani (Stewig, 2008). Pengembangan buku cerita bergambar ini harus sesuai dengan karakteristik anak-anak dan tujuan awal yang sudah disusun sehingga akan menghasilkan buku cerita yang sesuai dengan yang diharapkan pada rencana awal. Selain itu, ada keunggulan dalam penggunaan buku cerita bergambar ini sesuai dengan pendapat Stewig (2008), tiga keunikan menggunakan buku cerita bergambar yaitu mereka memberikan masukan bahasa untuk anak-anak, mereka memberikan masukan visual untuk anak, mereka menstimulasi kelancaran visual dan verbal anak-anak. Ketersediaan buku cerita ini juga dapat memacu kegemaran membaca pada anak.

Kemampuan dalam membaca teks merupakan salah satu hal yang harus dimiliki oleh seseorang. Membaca adalah proses yang kompleks dan rumit, mengindikasikan bahwa kemampuan membaca itu adalah kemampuan yang spesifik. Salah satu kemampuan penting dalam pembelajaran yang harus dikuasai oleh siswa yaitu kemampuan membaca. Membaca digunakan sebagai alat bahasa untuk komunikasi, secara sengaja dan internasional. Membaca merupakan kegiatan yang penting dan strategis, meskipun kenyataannya menunjukkan bahwa kualitas dan proses pembelajaran membaca di sekolah masih belum optimal (Wardoyo, 2016). Kemampuan membaca pada siswa akan lebih optimal jika pembelajarannya dilakukan secara sistematis, sehingga siswa nantinya akan menyukai kegiatan membaca tersebut tanpa adanya paksaan. Salah satu kegiatan yang dapat menumbukan kegemaran dalam membaca siswa yaitu melalui kegiatan literasi. Membaca juga akan membuat kosakata siswa berkembang, pengalaman dengan kata-kata ini membantu anak-anak dalam mengembangkan pemahaman konkret tentang dunia mereka dan kemudian diterapkan pengetahuan itu pada konsep yang lebih abstrak sebagai pacuan berkembangnya pengetahuan mereka (Massey, 2013).

Menulis merupakan salah satu kemampuan berbahasa yang harus dipelajari yang terkandung dalam Kurikulum 2013.9 Selain berbicara, menulis merupakan suatu kemampuan berbahasa yang penting (Cahyono, 2009). Keterampilan menulis merupakan salah satu tolak ukur untuk menunjukkan tingkat kecakapan literasi siswa (Rini, 2017). Menulis adalah salah satu keterampilan berbahasa yang produktif dan ekspresif yang digunakan untuk berkomunikasi tidak langsung dengan pihak lain. Menulis juga dapat menjadikan siswa lebih kreatif dalam menuangkan idenya berupa tulisan. Dengan menulis, siswa dapat mengekspresikan perasaan, pikiran, atau gagasan kepada orang lain, baik gagasan yang berasal dari diri penulis maupun gagasan yang berasal dari luar (Lestari, 2016).Sebagaimana pandangan strategi Quantum (Quantum learning and teaching) yang kini mulai populer, pemberian tugas menulis haruslah disiasati sedemikian rupa dengan memberikan kebebasan kreativitas kepada siswa agar tugas-tugas itu tidak membosankan, dan sebaliknya benar-benar mampu merangsang siswa untuk berekspresi dan berkreasi (Wahyuni, 2012).

Sejauh ini, pembelajaran yang dilakukan masih mengalami banyak kekurangan. Salah satunya yaitu masih kurangnya ketersediaan media pembelajaran sebagai upaya untuk mempermudah siswa dalam belajar. Media pembelajaran adalah segala sesuatu yang membawa informasi antara sebuah sumber dan sebuah penerima (Smaldino, 2011). Tujuan dari ketersediaan media adalah untuk memudahkan komunikasi serta penyampaian pesan dan proses belajar. Keberadaan media dalam kegiatan pembelajaran ini sangat penting terutama untuk memberikan pengalaman konkret yang nyata kepada siswa, terlebih kepada siswa SD.

Bertolak dari uraian tersebut, usaha mengembangkan media berupa buku cerita yang layak untuk meningkatkan efektivitas dan produktivitas belajar yang dipandang sebagai hal yang mendukung tercapainya kebermakanaan media. Pengembangan media buku cerita tersebut memiliki fungsi ganda dilihat dari manfaatnya. Hasil penelitian ini akan bermanfaat bagi (1) sekolah sebagai media pembelajaran yang dapat diimplementasikan dengan dampingan guru maupun secara mandiri, (2) siswa dapat dijadikan acuan untuk meningkatkan kemampuan membaca dan menulis.

\section{METODE}

Model penelitian yang digunakan pada penelitian berdasarkan pada model pengembangan Dick \& Carey, namun hanya fokus pada tahap penelitian ke sembilan. Penelitian pengembangan ini bertujuan untuk menghasilkan produk buku cerita untuk meningkatkan kemampuan membaca dan menulis siswa kelas IV Sekolah Dasar yang berupa buku cerita yang berjudul (1) Anak Iban Sahabat Mayas, (2) Batu Segilima di Gunung Padang, dan (3) Menunggu Pagi di Lok Baintan. 
Model pengembangan Dick \& Carey yang digunakan dalam penelitian ini sampai pada langkah kesembilan. Langkah pengembangannya sebagai berikut. Pertama, mengidentifikasi tujuan pembelajaran. Kedua, melakukan analisis pembelajaran. Ketiga, menganalisis kemmapuan awal dari karakteristik yang dimiliki siswa. Keempat, merumuskan tujuan khusus dalam pembelajaran. Kelima, mengembangkan instrumen atau alat penilaian. Keenam, mengembangkan strategi pembelajaran. Ketujuh, mengembangkan dan memilih materi pembelajaran dalam evaluasi formatif. Kedelapan, merancang dan melakukan evaluasi formatif. Kesembilan, melakukan revisi. Setyosari (2015) juga mendefinisikan penelitian pengembangan merupakan sebuah proses mengembangkan dan memvalidasi produk pendidikan.

Pada langkah identifikasi tujuan pembelajaran, langkah pertama yang dilakukan peneliti yaitu melakukan analisis terhadap kurikulum yang diterapkan dalam sekolah dasar tersebut, yaitu kurikulum 2013. Analisis kurikulum 2013 ini terdiri dari analisis buku guru dan analisis buku siswa yang sudah ada. Analisis ini dilakukan dengan cara observasi dan wawancara kepada guru dan siswa tentang implementasi kurikulum 2013. Pada langkah analisis pembelajaran, peneliti melakukan analisis tugas membaca dan menulis siswa, analisis proses pembelajaran yang dilakukan guru, dan materi pokok yang akan dikembangkan dengan klarifikasi rumusan tujuan pembelajaran tentang sikap, keterampilan, dan pengetahuan yang relevan. Pada langkah identifikasi karakteristik dan lingkungan siswa, peneliti menggali keterampilan/kemampuan yang sudah dimiliki siswa, kondisi lingkungan belajar siswa, serta tugas yang dihadapi siswa saat pembelajaran melalui teknik wawancara. Hasil analisis dari ketiga langkah awal penelitian dilanjutkan dengan empat langkah selanjutnya yaitu perumusan tujuan khusus, pengembangan instrumen, pemilihan strategi dan bahan pembelajaran. Pada langkah evaluasi formatif dilakukan dua kegiatan, yaitu validasi ahli dan uji coba pada pengguna. Uji produk oleh ahli dilakukan sebanyak tiga tahap, yaitu uji perorangan, uji kelompok kecil, dan uji lapangan.

Berdasarkan prosedur penelitian dan pengembangan, data prapengembangan yang dilakukan pada tiga langkah awal dalam penelitian ini berupa (1) hasil pengujian teori dan (2) hasil survei tentang kemampuan membaca dan menulis yang dimiliki siswa. Data (1) bersumber pada buku teori tentang kurikulum yang digunakan di sekolah dasar tersebut, yaitu kurikulum 2013 dan data (2) bersumber dari proses analisis hasil tugas siswa mengenai hasil membuat materi dalam meningkatkan kemampuan menulis siswa kelas IV sekolah dasar. karya berupa karangan siswa. Data yang sudah terkumpul pada tiga langkah awal tersebut dianalisis dan hasilnya dijadikan dasar pengembangan buku cerita yang terdiri dari empat langkah mulai dari perumusan tujuan khusus hingga pemilihan buku cerita. Data buku cerita pada penelitian mencakup kelayakan yang memenuhi kriteria pada aspek validitas dan kepraktisan. Data kepraktisan dari buku ceirta ini terdiri dari (1) kemenarikan tampilan buku cerita, (2) keterbacaan isi/materi dan kemudahan penggunaan, (3) ketersediaan materi dalam meningkatkan kemampuan membaca pada siswa kelas IV sekolah dasar, (4) ketersediaan.

Analisis data dilakukan secara deskriptif kualitatif dengan analisis data deskriptif kualitatif digunakan untuk mengolah data hasil review validator ahli isi/materi, validator ahli media, siswa dan guru dengan mengelompokkan informasi dari data kualitatif berupa masukan, tanggapan, kritik, dan saran perbaikan yang merupakan hasil dari validasi yang terdapat pada lembar validitas, lembar angket, dan hasil wawancara. Analisis data deskriptif kuantitatif digunakan sebagai bahan untuk mengolah data berupa skor/angka berdasarkan data yang diperoleh dari lembar validasi dan angket dalam bentuk deskriptif. Persentase yang diperoleh dari hasil validasi digunakan sebagai uji kelayakan produk buku cerita yang dinilai dari analisis validitas dan kepraktisan produk buku cerita.

\section{HASIL}

Hasil dari penelitian dan pengembangan ini berupa media pembelajaran yang diwujudkan berupa buku cerita anak, khususnya untuk Tema 1 Subtema 1 yaitu Keberagaman Budaya Bangsaku untuk siswa kelas IV SD dengan menggunakan model pengembangan Dick \& Carey (2009). Model penelitian dan pengembangan ini terdiri atas 10 tahapan, yaitu (1) mengidentifikasi tujuan; (2) melakukan analisis pembelajaran; (3) mengidentifikasi karaktersitik siswa; (4) merumuskan tujuan khusus; (5) mengembangkan instrumen penilaian; (6) mengembangkan strategi pembelajaran; (7) mengembangkan dan memilih bahan/materi pembelajaran; (8) merancang dan melaksanakan evaluasi formatif; (9) melakukan revisi; (10) mendesain dan membuat evaluasi sumatif, namun dalam penelitian ini hanya sampai pada tahap kesembilan.

Peneliti mengumpulkan informasi tentang ketersediaan penunjang pembelajaran berupa media di Sekolah Dasar 1 Sidomulyo Kecamatan Gondang Kabupaten Tulungagung melalui wawancara dengan Kepala Sekolah, Guru Kelas IV dan tiga orang siswa kelas IV sehingga diperoleh beberapa pernyataan. Ketersediaan media di Sekolah Dasar 1 Sidomulyo ini masih sangat terbatas, karena guru masih menggunakan media yang sudah disediakan dari pemerintah dan masih kurang guru yang bersedia untuk mengembangkan media sendiri sehingga ada beberapa materi yang pembelajarannya tanpa menggunakan ketersediaan media. Guru melakukan kegiatan belajar menggunakan buku dari kemendikbud sebagai acuan utamanya, dan hanya didampingi oleh buku latihan yang sudah disediakan dari dinas pendidikan Kabupaten Tulungagung. Hal tersebut mengakibatkan siswa masih kesulitan untuk menangkap materi pembelajaran sehingga banyak siswa yang akhirnya ramai sendiri pada waktu kegiatan belajar mengajar.

Studi pendahuluan di SDN 1 Sidomulyo yang dilakukan melalui wawancara dan observasi dilanjutkan pada tanggal 7 maret 2018 mengenai implementasi Kurikulum 2013. Sekolah ini menerapkan pembelajaran tematik di kelas IV sudah dua tahun berjalan. Berdasarkan hasil wawancara, observasi, dan analisis tugas siswa berupa karangan mandiri, dan analisis bahan 
ajar yang digunakan guru di kelas, pemanfaatan sumber belajar masih terpacu pada buku guru dan buku siswa dari pemerintah yang berberntuk soft file, ini pun jumlahnya terbatas hanya seperempat dari jumlah siswa sehingga hal ini menyebabkan siswa harus berkelompok dalam menggunakan buku tersebut. Selain itu, berfokus pada media, guru masih jarang sekali menyediakan media pada pembelajaran. Siswa dapat belajar dengan media hanya pada kemampuan ilmu pengetahan saja, sedangkan pada kemampuan yang lain masih sangat kurang.

Hasil analisis terhadap buku guru dan buku siswa dari pemerintah beserta tugas mandiri siswa berupa karangan di Sekolah Dasar 1 Sidomulyo menunjukkan beberapa temuan, yaitu (1) tulisan siswa masih jauh dari kriteria menulis cerita yang benar, (2) belum tersedia langkah-langkah penulisan cerita yang runtut baik pada buku guru dan buku siswa, (3) belum tersedia cerita tentang kebudayaan untuk anak-anak pada buku guru dan buku siswa, (4) aktivitas yang disediakan dalam buku guru dan buku siswa masih kurang terfokus pada beberapa kemampuan, dan (5) penyajian dalam buku guru dan buku siswa masih kurang berkreasi sehingga kurang dapat menstimulasi proses belajar siswa.

\section{Kemampuan Membaca dan Menulis Siswa Kelas IV SD}

Peneliti menggali kemampuan membaca siswa kelas IV yang berfokus pada tema Indahnya Kebersamaan pada subtema keberagaman budaya bangsaku dalam aplikasi pengetahuan dan pemahaman kemampuan membaca cerita. Tema I memiliki tujuan menumbuhkan sikap, keterampilan, dan pengetahuan yang menunjukkan siswa peduli dan memahami tentang kebudayaan bangsa. Berdasarkan hasil observasi, ketersediaan media dalam pembelajaran masih kurang, khususnya media untuk meningkatkan kemampuan membaca dan menulis pada siswa. Melalui wawancara, peneliti menggali informasi mengenai penggunaan media yang disediakan oleh guru pada siswa dan buku-buku yang digunakan untuk menunjang proses pembelajaran serta pengetahuan dan pemahaman siswa mengenai cerita, dan hasilnya yaitu guru hanya menggunakan media pada kemampuan ilmu pengetahuan alam dan pada kemampuan membaca dan menulis masih kurang.

Bertolak dari temuan tersebut, peneliti melalukan observasi dan wawancara lagi mengenai perangkat pembelajaran yang digunakan oleh guru terdiri dari RPP dan silabus. Berdasarkan observasi tersebut didapati bahwa perangkat pembelajaran yang digunakan guru masih perangkat dari pemerintah yang sifatnya bertahun-tahun tidak mengalami perubahan tanpa adanya Pengembangan sehingga kurang sesuai dengan karakteristik siswa di Sekolah Dasar 1 Sidomulyo, Tulungagung. Perangkat yang berasal dari pemerintah tersebut sebagian besar materinya menggunakan kondisi geografis perkotaan, sedangkan kondisi di sekolah dasar 1 Sidomulyo ini termasuk kawasan pedesaan. Sementara itu, siswa masih kesulitan dalam membayangkan materi yang mereka pelajari karena seharusnya hal itu didukung dengan ketersediaan media sehingga mudah dipahami oleh siswa dimana materinya tidak sesuai dengan kondisi geografis tempat mereka tinggal.

Penjabaran kondisi di atas belum sepenuhnya memenuhi prinsip pembelajaran berbasis Kurikulum 2013 dimana, (1) dari peserta didik diberi tahu menuju peserta didik mencari tahu, (2) dari guru sebagai sebagai satu-satunya sumber belajar berbasis aneka sumber belajar, (3) dari pendekatan tekstual menuju proses sebagai penguatan penggunaan pendekatan ilmiah atau saintifik, (4) dari pembelajaran verbalisme menuju keterampilan aplikatif, dan (5) peningkatan dan keseimbangan antara keterampilan fisikal (hardskill) dan keterampilan mental atau softs skill (Permendikbud Nomor 22 Tahun 2016). Kurikulum 2013 memberi ruang untuk kreatif bagi guru dalam mengimplementasikan kurikulum baik dalam mengembangkan tema dan subtema dengan konteks yang relevan dengan tetap berpacu pada proses ilmiah yang meliputi mengamati, menanya, mencoba, menalar, dan mengomunikasikan. Berdasarkan kurikulum yang diterapkan saat ini dapat menjadi wadah guru untuk lebih kreatif dan inovatif dalam ketersediaan media pembelajaran.

\section{Prototipe Buku Cerita Keberagaman Budaya Bangsaku}

Produk yang dihasilkan berupa media pembelajaran berupa buku cerita dan bercirikan cerita tentang kebudayaan pada Tema Indahnya Kebersamaan pada subtema Keberagaman Budaya Bangsaku untuk kelas IV SD. Buku cerita dikembangkan dengan mengikuti langkah-langah pada model Dick \& Carey sampai pada langkah kesembilan. Model pengembangan Dick \& Carey dipilih karena memiliki keunggulan yaitu menggunakan pendekatan sistem dan memenuhi keempat karakteristik yang harus terpenuhi dalam pengembangan produk buku cerita.

Kajian produk media ini berupa buku cerita yang mencakup desain fisik, desain teks, desain visual, dan komponen isi buku cerita. Ciri-ciri buku ajar, meliputi (1) sumber materi ajar; (2) menjadi referensi baku untuk materi tertentu: (3) disusun sistematis dan sederhana; (4) disertai petunjuk pembelajaran. Desain fisik yang dimaksud terdiri atas identitas, halaman sampul, dan halaman isi. Media sendiri juga memiliki prinsip-prinsip dalam pemilihannya. Sebagaimana diungkapkan oleh Musfiqon (2012), prinsip-prinsip pemilihan media, meliputi (1) efektivitas dan efisiensi, (2) relevansi, dan (3) produktivitas.

Buku cerita ini diberi judul sesuai dengan isi cerita yang ada di dalamnya. Cover bagian depan buku berisi judul buku cerita, identitas, sasaran, dan gambar ilustrasi, sedangkan pada cover belakang berisi tentang ilustrasi keadaan sesuai dengan cerita yang ada pada isi buku. Cover dibuat dengan aplikasi Photoshop. Ilustrasi pada cover depan dan belakang terdapat pada gambar 1. 

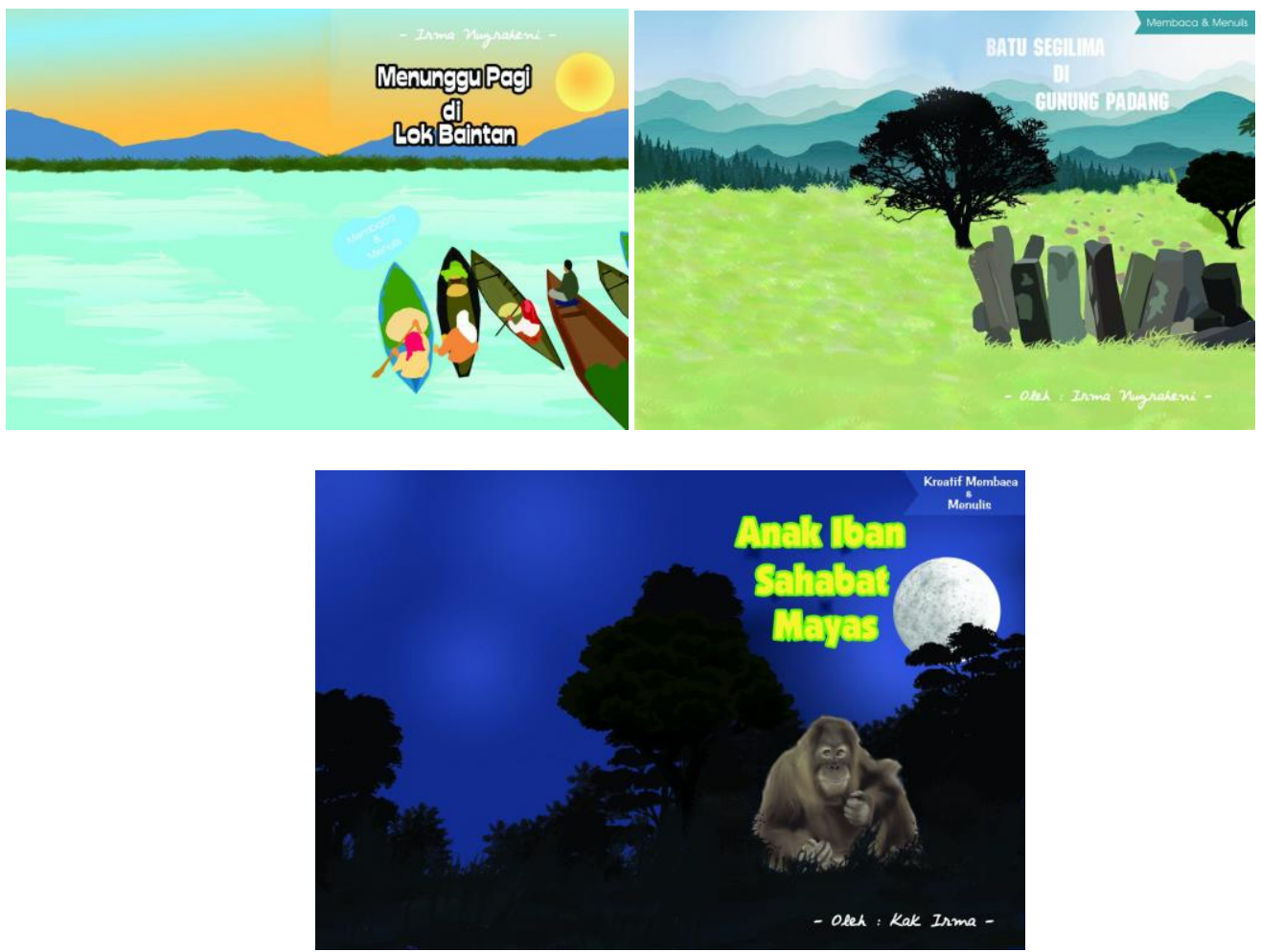

\section{Gambar 1. Cover pada Buku Cerita}

Ukuran kertas yang digunakan untuk mencetak buku cerita ini yaitu A5 dengan berat 100 gsm. Pertimbangan dalam pemilihan kertas adalah kesesuaian dengan kebutuhan pengembangan desain, tata letak, penulisan, ilustrasi dan karakteristik siswa sekolah dasar yang masih menyukai sesuatu yang berbentuk berbeda/unik daripada yang pada umumnya. Desain teks pada buku cerita ini terdiri dari ukuran, jenis, dan spasi. Buku cerita keberagaman budaya bangsaku ini sebagian besar menggunakan jenis teks Comic Sans MS dengan variasi penggunaan ukuran font font 14. Spasi yang digunakan adalah 1,5. Pada sebagian teks ada yang menggunakan spasi 2 dengan tujuan tulisan dapat terbaca dengan jelas. Desain visual meliputi penggunaan warna, gambar, dan ilustrasi gambar dengan warna lain. pemilihan warna juga mempertimbangkan karakteristik yang ada pada siswa kelas IV sekolah dasar sehingga siswa merasa senang ketika menggunakan buku cerita ini. Gambar dan ilustrasi disajikan sebagian besar dengan menggunakan gambar nyata dan sebagian kecil menggunakan gambar kartun sehingga dapat bervariasi. Pertimbangannya adalah supaya siswa merasa lebih mendalami isi dari cerita yang mereka pelajari.

Komposisi buku mencakup bagian awal, bagian isi, dan bagian akhir buku. Bagian awal buku cerita berisi halaman cover, halaman judul, kata pengantar, daftar isi, peta konsep, kompetensi dasar, indikator, dan petunjuk penggunaan buku cerita. Gambar 2 menampilkan bagian awal buku cerita.
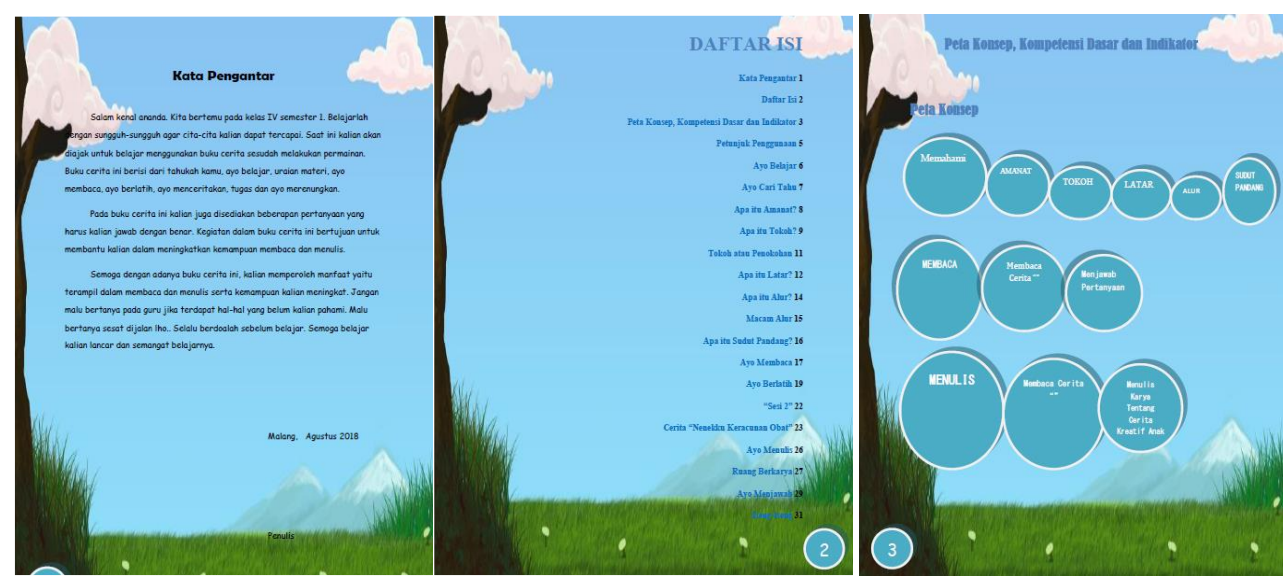

Gambar 2. Bagian Awal Buku Cerita 
Bagian isi pada buku cerita terdiri dari urutan penulisan cerita yang benar. Pada buku cerita ini juga disediakan pertanyaan pemahaman tentang cerita sebelumnya yang sudah disediakan juga pada buku cerita. Sebagai tujuan utama dari ketersediaan buku cerita ini peneliti juga menyediakan tempat untuk menulis cerita pada ruang berkarya yang terdapat pada halaman terakhir di produk buku cerita sebagai langkah untuk meningkatkan kemampuan membaca dan menulis siswa. Pada gambar 3 menampilkan bagian isi buku cerita.
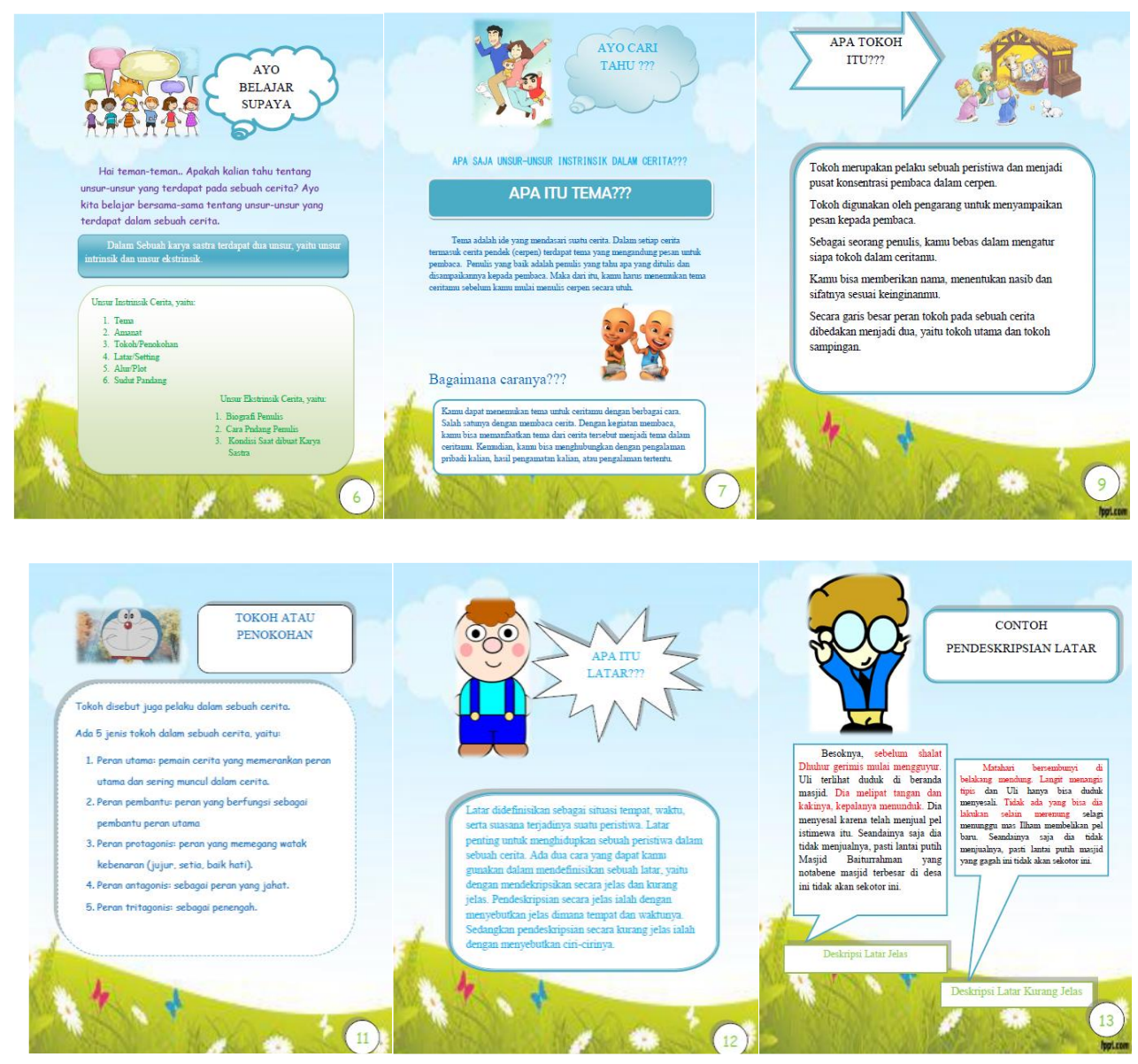

Gambar 3. Bagian Isi Buku Cerita

\section{Kajian Kelayakan Produk}

Kelayakan produk ditinjau dari hasil validitas dan kepraktisannya. Validitas produk buku cerita ini termasuk pada kriteria sangat valid dengan perolehan persentase 93\%. Meskipun demikian, ahli media dan ahli materi memberi catatan dan masukan agar ditindaklanjuti untuk revisi sebelum dilankukan uji coba lapangan. Catatan dari para ahli media di antaranya besar kecil huruf harus lebih diperhatikan supaya lebih terbaca oleh siswa, penggunaan gambar dan tata letak pada halaman juga harus di desain lebih kreatif lagi supaya lebih terlihat menarik. Catatan dari ahli materi yang paling mendasar, yaitu penggunaan kalimat harus lebih disederhanakan agar lebih mudah dipahami oleh anak-anak.

Kepraktisan produk dinilai dari relevansi isi, format penyajian media, penggunaan bahasa, kesederhanaan media, keterpaduan dengan pembelajaran, dan penekanan terhadap pembelajaran. Pada uji coba perorangan, kemenarikan produk media buku cerita mendapat persentase $84,11 \%$ atau pada kategori sangat menarik. Setelah dilakukan revisi, maka dilakukan kembali uji coba pada kelompok kecil yang menghasilkan persentase 91,77\% dan termasuk pada kategori sangat menarik. Pada tahap uji coba ini mendapatkan masukan sebagai acuan untuk perbaikan sebelum dilakukan uji coba lapangan. Pada uji coba lapangan, kemenarikan produk mendapatkan persentase sebesar 93\% dengan kriteria sangat menarik.

\section{PEMBAHASAN}

Hasil dari penilaian para ahli menunjukkan bahwa latihan-latihan yang terkandung dalam buku cerita telah layak untuk digunakan dalam kegiatan belajar mengajar, dan mampu meningkatkan kemampuan membaca dan menulis siswa kelas IV SD. Berangkat dari pernyataan tersebut maka sebagai pendidik harus memberikan yang terbaik dalam proses belajar mengajarnya. 
Hal ini mengisyaratkan bahwa dalam proses belajar mengajar siswa harus dijadikan sebagai pusat dari kegiatan (Sanjaya, 2008). Siswa sebagai pusat kegiatan belajar tersebut tentunya membutuhkan alat bantu dalam proses belajar mengajar yaitu berupa media pembelajaran. Media adalah sarana pembelajaran serta pengembangan media (Ardi, 2018). Ketersediaan media yang sesuai dengan topik belajar menjadi pusat perhatian yang harus diperhatikan guru untuk mampu menghadirkan media dalam setiap proses belajar. Hal tersebut membuat anak-anak menjadi gemar belajar sambil bermain dengan media yang menyenangkan dan mendidik (Rahmawati, 2016).

Pelaksanaan kegiatan belajar mengajar dengan menggunakan media buku cerita ini dapat digunakan secara berkelompok maupun mandiri. Pada buku cerita ini juga disajikan tahap-tahap penulisan cerita dengan benar dan disertai dengan contoh sehingga akan mempermudah siswa dalam mempelajari cara menulis cerita dengan benar. Penyajian tahap-tahap penulisannya disesuaikan dengan urutan dalam menulis cerita sehingga siswa tidak perlu memilih tahapannya lagi. Selain itu, dalam buku cerita juga disajikan gambar-gambar yang menarik dan disajikan dengan warna yang sesuai dengan karakter gambar. Hal tersebut akan memberikan dampak pada minat belajar siswa. Hal tersebut terbukti dengan antusiasnya siswa dalam menggunakan media buku cerita ini dalam kegiatan belajar mengajar. Seperti yang diungkapkan oleh Palaiologou (2013) bahwa anak-anak harus dapat belajar melalui pengalaman menyentuh, bergerak, mendengarkan, dan melihat.

Penggunaan media buku cerita ini juga menjadikan siswa aktif bekerja kelompok dengan temannya baik satu kelompok maupun lain kelompok. Pada buku cerita ini terdapat tugas kelompok yang harus dikerjakan dengan teman satu kelompoknya dan bertukar pendapat dengan kelompok lain. Interaksi sosial dalam kegiatan ini terjadi sehingga sosial anak juga akan semakin meningkat. Interaksi sosial dapat terjadi dari satu jenis ke jenis interaksi yang lain dan kehadiran perilaku agresif kemungkinan tidak akan menghalangi kegiatan selama interkasi itu bersifat menyenangkan (Hill, 2017). Kualitas interaksi teman sebaya sering dianggap sebagai indikator kompetensi sosial pada anak muda di Indonesia (Gagnon, 2014). Penggunaan media buku cerita ini menjadikan siswa belajar aktif, dan guru sebagai fasilitator sekaligus membimbing penggunaan media. Hal tersebut sesuai dengan yang diungkapkan oleh Edwards (2013) yaitu kami tertarik dengan guru yang mengidentifikasi sesuatu sebagai dasar konseptual dari keterlibatan mereka dengan anak-anak dan strategi pedagogis yang ingin mereka gunakan dengan anakanak ketika menggunakan sesuatu yang berbeda baik dari jenis permainan pedagogis yang terkait dengan pendidikan anak usia dini, termasuk permainan yang membuka pikiran siswa maupun permainan yang sengaja dibingkai.

\section{SIMPULAN}

Produk yang dihasilkan dalam penelitian pengembangan ini berupa media pembelajaran yang berwujud buku cerita untuk siswa sekolah dasar kelas IV. Sebagai media pembelajaran pada tema 1 subtema 1 yaitu Keberagaman Budaya Bangsaku. Media buku cerita ini terdiri dari tiga macam buku dengan judul yang berbeda-beda, yaitu (1) Anak Iban Sahabat Mayas, (2) Batu Segilima di Gunung Padang, dan (3) Menunggu Pagi di Lok Baintan. Pada masing-masing buku terdapat latihan-latihan dilengkapi dengan contoh yang dapat meningkatkan kemampuan membaca dan menuli siswa. Latihan membaca yang dimaksud berupa disediakannya cerita-cerita anak dan kebudayaan sehingga siswa memiliki pengetahuan tentang cerita dan latihan menjawab pertanyaan-pertanyaan mengenai isi cerita yang sudah dibaca oleh siswa.

Latihan menulis yang dimaksud adalah berupa tersedianya ruangan berkarya untuk siswa menuliskan karya hasil karangan siswa tentang cerita kesehariannya berdasarkan petunjuk yang sudah ada di buku. Sebelum siswa menuliskan karyanya di ruang berkarya, disitu juga telah tersedia unsur-unsur yang harus ada dalam penulisan cerita yang baik dilengkapi dengan contoh penulisan cerita yang sudah benar. Berdasarkan hasil dari uji kelayakan baik dari ahli media, ahli materi, guru dan siswa kelas IV Sekolah Dasar 1 Sidomulyo dapat disimpulkan bahwa buku ini layak untuk digunakan dalam kegiatan pembelajaran. Selain itu, berdasarkan dari uji keefektifan yang dilakukan guna mendukung hasil penelitian ini maka diperoleh hasil bahwa media buku cerita keberagaman budaya bangsaku dapat meningkatkan kemampuan membaca dan menulis siswa sekolah dasar kelas IV.

Saran pengembangan produk buku cerita ini mempertimbangkan pada prosedur penelitian dan pengembangan yang telah mencapai proses empat kali revisi sesuai dengan saran ahli dan pengguna (guru dan siswa) pada proses validasi dan uji coba terbatas secara perorangan, kelompok, dan lapangan. Produk ini juga dapat dikembangkan lebih lanjut dengan tema atau subtema, jenjang kelas, maupun jenis teks yang digunakan serta dilengkapi atau ditunjang dengan multimedia sebagai upaya pengembangan era global. Peneliti dan pengembang selanjutnya juga dapat fokus pada pengembangan buku cerita dengan menambahkan kemampuan yang dapat ditingkatkan melalui buku cerita yang akan dikembangkan sehingga tidak hanya dapat meningkatkan kemampuan membaca dan menulis saja dan hasilnya akan lebih optimal.

\section{DAFTAR RUJUKAN}

Ardi, Z., Viola., K., \& Sukmawati, I. (2018). An Analysis of Internet Abuses Impact on Children's Moral Development. Jurnal Penelitian Pendidikan Indonesia, 4(1), 44-50. DOI : https://doi.org/10.29210/02018192

Cahyono, B. (2009). Techniques in Teaching EFL Writing. Malang: University of Malang Press.

Carr, M., \& Lee., W. (2012). Learning Stories Constructing Learner Identities in Early Education. London: British Library Cataloguing in Publication Data.

Carey, J. O, Lou Carey., \& Walter Dick. (2009). The Systematic Design of Intructional (7 ${ }^{\text {th }}$ Edition). Ohio: Pearson. 
Edwards, S., Cutter, A., \& Mackenzie. (2013). Pedagogical Play Types: What Do They Suggest for Learning about Sustanability in Early Childhood Education?. International Journal of Early Childhood, 45(3), 327-346. DOI 10.1007/s13158-013-0082-5.

Fahmi, S. (2017). Pengembangan Media Pembelajaran Interaktif untuk Kursus Logika Matematika dan Set. Prosiding Konferensi Internasional Ahmad Dahlan tentang Pendidikan Matematika, ISBN 978-979-3812-53-3.

Faizah, U. (2009). Keefektifan Cerita Bergambar untuk Pendidikan Nilai dan Keterampilan Berbahasa dalam Pembelajaran Bahasa Indonesia. Cakrawala Pendidikan, 28(3), 249-256.

Gagnon, S., Huelsman, T., \& Reichard, A. (2014). Help Me Play! Parental Behaviours, Child Temperament, and Preschool Peer Play. Journal of Child and Family Studies, 23(5), 872-884. DOI 10.1007/s10826-013-9743-0

Hamalik, O. (2011). Kurikulum dan Pembelajaran. Bandung: Bumi Aksara.

Hill, H., Dietrich, S., \& Cappiello, B. (2017). Learning to Play: A Review and Theoritical Investigation of the Developmental Mechanisms and Function of Cetacean Play. Learning \& Behavior, 45(4), 335-354. DOI 10.3758/s13420-017-0291-0.

Inal, Y., \& Cagitaly, K. (2007). Flow Experiences of Children in an Interactive Social Game Environment. British Journal of Educational Technology, 38(3), 455-464.

Kemendikbud. (2016a). Desaian Induk Gerakan Literasi Sekolah. Jakarta: Dirjen Dikdasmen Kemendikbud.

Lestari. (2016). Efektivitas Media Video Panorama dengan Strategi Metakognitif dalam Pembelajaran Menulis Teks Deskripsi Siswa Kelas VII SMPN 1 Karangploso. Pusat Kajian Bahasa dan Budaya, Surakarta, Indonesia, 13(2), $231-241$.

Massey, S.( 2013). From the Reading Rug to the Play Center: Enhancing Vocabulary and Compehensive Laguage Skills by Connecting Skills by Connecting Storybook Reading and Guided Play. Early Childhood Education Journal, 41(2), $125-131$.

Musfiqon. (2012). Pengembangan Media Belajar dan Sumber Belajar. Jakarta: Prestasi Pustaka Karya.

Nugraha, R., Degeng, S., Hanurawan, F., \& Chusniah, T. (2016). Process of Self Regulated Learning an Student's Strategic Studies Activities in Learning Environment. International Conference on Education. Education in the $21^{\text {th }}$ Century: Responding to Current Issues. 747-753.

Nurjanah, E., \& Hakim, D. (2018). Pengembangan Bahan Ajar Materi Mencerna (Menyimak Cerita Anak) Berbasis Cerita Anak Majalah Bobo pada Siswa Kelas VI MI Darum Najah I Jatirejo Mojokerto. Jurnal Bidang Pendidikan Dasar, 2(1), $69-83$.

Nurmanita, T., Harsiati, T., \& Suyono. (2017). Cerita Anak sebagai Sarana Pendidikan Karakter di Sekolah Dasar. Prosiding TEP \& PDs Transformasi Pendidikan Abad 21, 7(9),1100-1105.

Palaiologou, I. (2013). The Early Years Foundation Stage Theory and Practice Second Edition. Wasington DC: SAGE Publications Ltd.

Rahmawati, I. (2016). CD Interaktif sebagai Media Pembelajaran Berbahasa bagi Anak Usia Dini di Ponorogo. Jurnal INDRIA: Ilmiah Pendidikan Pra Sekolah dan Sekolah Awal, 1(1), 9-21. DOI: 10.24269/jin.v1n1.2016.

Rini, T., Harsiati, T., \& Basuki, I. A. (2017). Asesmen Autentik Menulis untuk Menunjang Penerapan Gerakan Literasi di Sekolah Dasar. Prosiding TEP \& PDs Tranformasi Pendidikan Abad 21. Tema 4 Nomor 46. 498-506.

Sanjaya, W.( 2008). Kurikulum dan Pembelajaran. Bandung: Kencana Prenada Media Group.

Setyosari, P. (2015). Metode Penelitian Pendidikan dan Pengembangan Edisi Keempat. Jakarta: Prenada Media Grup.

Smaldino, S. E. (2011). Instructional Technology \& Media for Learning. USA: Pearson Prentice Hall.

Sujiono, N., \& Sujiono, B. (2010). Bermain Kreatif Berbasis Kecerdasan Jamak. Jakarta: PT Indeks.

Wahyuni, S., \& Ibrahim, A. S. (2012). Asesmen Pembelajaran Bahasa. Malang: PT Refika Aditama.

Wardoyo, H., Suyitno, I., \& Suyono. (2016). Bahan Ajar Membaca Kritis-Kreatif untuk Siswa SMP. Jurnal Pendidikan Humaniora, 4(1), 22-35. 